\title{
İlkokul Öğrencilerinin Okul Kavramına Yönelik Algıları: Metafor Çalışması ${ }^{1}$
}

\author{
$\ddot{\mathbf{O z}}$
}

\author{
Ramazan ERTÜRK*
}

\begin{abstract}
İlkokul öğrencilerinin okul kavramına yönelik metaforik algılarını belirlemeyi amaçlayan araştırmanın çalışma grubunu kolay ulaşılabilir durum örneklemesine göre belirlenen Bolu ili Yeniçağa ilçesinde bulunan üç ilkokulda 2017-2018 eğitim-öğretim yılında öğrenim gören 124 ilkokul öğrencisi oluşturmaktadır. Araş̧ırmada nitel araştırma desenlerinden durum çalışması tekniği kullanılmıştır. Veriler yarı yapılandırılmış sorulardan oluşan form kullanılarak toplanmıştır. Toplanan veriler nitel araştırma desenine uygun olarak içerik analizi ile çözümlenmiştir. Elde edilen veriler doğrultusunda kodlar ve kavramsal kategoriler oluşturulmuştur. Kodlar ve kavramsal kategoriler belirlenirken iki uzmanın görüşüne başvurulmuştur. Verileri daha iyi yorumlayabilmek için yüzde ve frekanslara yer verilmiştir. Araştırma sonucuna göre, öğrencileri okul kavramına yönelik 32 metafor üretmişlerdir. Öğrenciler okul kavramını en çok lunapark, oyun, ev, aile, yuva, güneş, harita, pusula, anne, fener ve tiyatro metaforlarıyla açıklamışlardır. Öğrencilerin okul kavramına yönelik ürettikleri metaforlar güvenli ve huzur verici okul, eğlendirici okul, aydınlatıcı ve bilgilendirici okul, yönlendirici okul, şekillendirici okul, ve çalışma yeri olarak okul olarak altı kavramsal kategoride toplanmıştır Öğrencilerin okul kavramına yönelik ürettikleri metaforlar en çok güvenli ve huzur verici okul ile eğlendirici okul kategorilerinde yer almaktadır.
\end{abstract}

Anahtar Kelimeler: Okul, Metafor, Öğrenci, Okul Algısı

\section{Primary School Students' Perceptions on the Concept of School: Metaphor Study}

\begin{abstract}
The study group, which aims to determine the metaphorical perceptions of primary school students towards the concept of school, consists of 124 primary school students studying in three primary schools in Yeniçağa district of Bolu province, determined according to the easily accessible situation sampling, in the 2017-2018 academic year. Case study technique, one of the qualitative research designs, was used in the research. The data were collected using a form consisting of semi-structured questions. The collected data were analyzed by content analysis in accordance with the qualitative research design. Codes and conceptual categories were created in line with the data obtained. Two experts were consulted while determining the codes and conceptual categories. Percentages and frequencies are included in order to better interpret the data. According to the results of the research, their students produced 32 metaphors about the concept of school. The students mostly explained the concept of school with the metaphors of amusement park, game, home, family, home, sun, map, compass, mother, lantern and theater. The metaphors that students produce for the concept of school are categorized into six conceptual categories: a safe and peaceful school, an entertaining school, an enlightening and informative school, a guiding school, a formative school, and a school of study. The metaphors students produce for the concept of school are mostly included in the categories of safe and peaceful school and entertaining school.
\end{abstract}

Keywords: School, Metaphor, Student, School Perception

Geliş/Received: 15.07 .2021

Kabul/Accepted: 30.12 .2021

- Bu çalışma için, Bolu Abant İzzet Baysal Üniversitesi Sosyal Bilimlerde İnsan Araştırmaları Etik Kurulu'nun 01.02.2021 tarih ve 2021/01 toplantısında (Protokol NO. 2021/03) değerlendirilerek etik olarak uygun bulunmuştur.

\footnotetext{
${ }^{1} \mathrm{Bu}$ çalışmanın kısa metni 11-14 Nisan 2018 tarihinde Ankara'da düzenlenmiş olan 17. Uluslararası Sınıf Öğretmenliği Sempozyumunda sözlü bildiri olarak sunulmuştur.

*Dr., Milli Eğitim Bakanlığı, koroglu522@hotmail.com, ORCID ID: 0000-0002-8140-0895.

(Makale Türü: Araştırma Makalesi)
} 


\section{Giriş}

Toplumsal kalkınmada ve insan gücünün yetiştirilmesinde en önemli örgütlerden biri okullardır. Okulların temel görevi kültürel öğeleri ve değerleri nesilden nesile aktararak toplumsal kültürün devamlılığını ve bireylerin toplumsallaşmasını sağlamaktır. Okul insanların sosyal, kültürel ve mesleki yaşamlarında çok önemli etkilere sahiptir (Cerit, 2006). Okulun toplumsal davranışların kazandırılmasında önemli bir rolü vardır (Dewey, 2019). Okullar, eğitim sisteminin paydaşlarını etkilediği gibi bireyin gelişiminde de büyük rol oynamaktadır (Örücü, 2014). Devletler eğitim yasaları ile okullardan beklentilerini açıklamaktadırlar. Bu beklentiler genellikle iyi bir insan, iyi bir yurttaş, iyi bir üretici ve bilinçli vatandaşlar yetiştirmek olarak ifade edilmektedir. Günümüzde de okullardan beklenti oldukça fazladır (Aydın, 2012). Ancak bu beklentilerin karşılanması, okulların sadece yeterli insan kaynağına ve donanıma sahip olmasıyla mümkün değildir. Okulların en önemli paydaşlarından biri olan öğrencilerin okula ilişkin duygu ve düşünceleri, okulu nasıl algıladıkları, okuldaki deneyimlerini yorumlama biçimlerinin ortaya çıkarılması da okulların sahip oldukları insan kaynağı, insan kaynağının niteliği ve okulların fiziksel yeterlikleri kadar önemlidir. Okulu sadece girdileri olan ve bu girdileri işleyerek ürün elde ederek üretim gerçekleştiren örgütler olarak görmek ve bu şekilde düşünmek eğitimin ve okulun doğasına uygun değildir. Sosyal bir sistem olan okul, içerisinde çok sayıda insan kaynağını barındıran bir yaşam alanıdır. Okulu ve okulun sahip olduğu insan faktörünü nesnel olarak ele almak, insanın duygu, düşünce ve hislerini görmezlikten gelmektir. Bu düşünce ve bakış açısı okulu tam olarak anlamada ve ifade etmede yeterli bir bakış açısı değildir (Nalçacı ve Bektaş, 2012). Dolayısıyla okulda yürütülen eğitim öğretim faaliyetlerinin verimli ve etkili olmasında ve nihayetinde öğrencilerin başarıya ulaştırılmasında öğrencilerin okula yönelik tutumları ve algıları ön plana çıkmaktadır. Öğrenci ile okul arasındaki bağ, öğrencinin okulda gerçekleştirilen faaliyetleri özümsemesini ve içsel olarak bu faaliyetlere katılarak yetiştirilmesini sağlayacaktır. Çünkü bireyin, örgüt yapısını kavramsallaştırma biçimi ve örgütü algılama durumuna yönelik benzetimleri, bireyin örgüt ile arasındaki ilişki hakkında önemli bilgiler verebilmektedir. $\mathrm{Bu}$ anlamda örgüt yapısını ve sistemlerini anlamada güçlü araçlar olarak görülen metaforların önemi ortaya çıkmaktadır. Çünkü metaforlar akıldaki soyut imge ve kavramları somut hale getirmede önemli işlevlere sahiptirler (Mazlum ve Balc1, 2018). Temel bir zihin mekanizması olan metaforlar, fiziksel ve sosyal tecrübe konusunda bilinenleri kullanma olanağı vererek birçok şeyin kavranmasını sağlamaktadırlar (Lakoff ve Johnson, 2005). Metaforlar eğitimi destekleyen teorilerin temelidir. Dolayısıyla eğitimin her kademesinde kullanılabilir (Botha, 2009). Nitekim metaforlar aracılığıyla eğitim süreçlerinin araştırılmasında ve anlaşılmasında; öğretmen, öğrenci, yönetici ve velilerin eğitim ve uygulamalara yönelik algıları incelenebilir, anlaşılabilir ve açıklanabilir (Yob, 2003).

Bireylerin dünya görüşü, mevcut bakış açısı, okul ve çevresinde meydana gelen değişimler, okuldan beklentiler okula yüklenen anlamların farklılık göstermesine neden olabilmektedir (Kara ve Bozbayındır, 2019). Dolayısıyla bu etkilere bağlı olarak öğrencilerin okula bakış açısı ve okula 
yükledikleri anlamlar ve okulu algılama biçimleri de farklılık gösterebilir. Öğrencilerin okula, derse ya da öğretmene yönelik zihinsel algıları metaforlarla belirlenebilmektedir. Öğrencilerin olumlu ve olumsuz zihinsel imgeleri eğitimi doğrudan etkileyebilmektedir (Doğan, 2014). Okul ve öğretmenlerin gelecek nesillerin yetiştirilmesinde ve şekillendirilmesinde eğitim ve öğretim sürecinin etkili şekilde yürütülmesinde önemli görev, rol ve sorumlulukları vardır. Okul ve öğretmenlerin bu rol ve sorumluluklarını yerine getirebilmelerinde öğrencilerin okula karşı duygu ve düşünceleri önem arz etmektedir. Nitekim öğrenci, öğretmen, yönetici ve ailelerin duygu ve düşüncelerini anlamay1 kolaylaştırmak için yararlanılmakta olan metaforlar, eğitim-öğretim sürecinin etkili bir şekilde yürütülmesinde kullanılabilmektedir (Ateş, 2016). Dolayısıyla okulun öğrenciler tarafından nasıl algılandığı asıl amacı öğrenciyi yetiştirmek, geliştirmek ve toplumsal kalkınmaya katkıda bulunacak iyi bir vatandaş olarak yetiştirmek olan okulların başarıya ulaşmasında oldukça önemlidir. Bu bağlamda ilkokul öğrencilerinin okul kavramına yönelik algılarını metaforik olarak ortaya çıkarmayı amaçlayan araştırmada aşağıdaki sorulara cevap aranmıştır:

1.İlkokul öğrencilerinin okul kavramına yönelik metafor algıları nelerdir?

2.İlkokul öğrencilerinin, okul kavramına yönelik metafor algıları hangi kavramsal kategoriler altında toplanmaktadır?

\section{Araştırmanın Önemi}

Gelecek nesillerin eğitilip yetiştirilmesinde okullara ve okullarda görevli personele önemli görev ve sorumluluklar düşmektedir. Öğrencilerin iyi bir vatandaş olarak yetiştirilip gelecekte ülke ekonomisine katkı sunmaları sadece okulların ve insan kaynağının varlığı ile mümkün değildir. Öğrencilerin okula yönelik algıları da bu bağlamda oldukça önem taşımaktadır. Dolayısıyla bu araştırmada ilkokul öğrencilerinin okula yönelik algıları ortaya çıkarılmaya çalışılmıştır.

\section{Yöntem}

\section{Araştırmanın Modeli}

Araştırmada araştırmacılara güncel bir olguyu kendi yaşam çerçevesinde ele alıp, nasıl ve neden sorularına odaklanarak amaçlanan durumu derinlemesine ve ayrıntılı biçimde inceleme firsatı vermekte olan (Yin, 2003) nitel araştırma desenlerinden durum çalışması tekniği kullanılmıştır. Bu bağlamda öğrencilerin okul kavramına yönelik algıları belirlenmiştir. Veriler durum çalışmasına uygun olarak görüşme yöntemi kullanılarak toplanmıştır. Görüşme sırasında öğrencilere formun nasıl doldurulacağ1 konusunda gerekli açıklamalar yapılmıştır. Bu araştırma Bolu Abant İzzet Baysal Üniversitesi Sosyal Bilimlerde İnsan Araştırmaları Etik Kurulunun 01.02.2021 tarih ve 01 sayılı toplantısında etik olarak uygun bulunmuştur. 


\section{Çalışma Grubu}

Araştırmanın çalışma grubunu 2017-2018 eğitim-öğretim yılında Bolu ili Yeniçağa ilçesinde üç ilkokuldaki 3. ve 4. sınıflarda öğrenim gören 124 öğrenci oluşturmaktadır. Örneklem seçiminde araştırmacıya hız ve pratiklik sağlayan kolay ulaşılabilir durum örneklemesi kullanılmıştır. Çalışma grubunda yer alan öğrencilerin \% 46.8'i kız (n=58), \% 53.2'si erkek (n=66); \% 49'u 3. sınıf öğrencisi (n=61), \%51'i 4. sınıf öğrencisidir ( $\mathrm{n}=63)$.

\section{Verilerin Toplanması ve Analizi}

Araştırmanın verileri literatürde metafor çalışmalarında kullanılan ve araştırmacı tarafından araştırma konusuna uygun olarak hazırlanan yarı yapılandırılmış form ile toplanmıştır. Öğrencilere dağıtılan formda okul. ..gibidir. Çünkü. .cümlesini tamamlamaları istenmiş ve oluşturdukları metaforlar nitel araştırma yöntemlerinden içerik analizi ile çözümlenmiştir. İçerik analizi, birbirine benzeyen verileri belli kategoriler ve temalar çerçevesinde bir araya getirerek, okuyucunun anlayabileceği bir şekilde organize edip yorumlamaktır (Yıldırım ve Şimşek, 2013; Balc1, 2015). Öğrencilerin verdikleri cevaplar doğrultusunda kodlar ve temalar oluşturulmuştur. Ayrıca metaforların oluşturduğu kavramsal kategorilere örnek oluşturması açısından bazı öğrencilerin görüşleri doğrudan alıntı şeklinde sunulmuştur.

\section{Geçerlik ve Güvenirlik}

Geçerlik ve güvenirlik, araştırmanın kuramsal çerçevesinin oluşturulması, verilerin toplanması, analizi ve yorumlanması ve bulguları kapsayan önemli kaygılardır (Merriam, 2013). Geçerlik kapsamında, yarı yapılandırılmış form kullanılarak öğrencilerden gelen cevaplar sonucunda elde edilen veriler kapsamlı bir şekilde incelenerek okul kavramına yönelik 32 metafor üretildiği tespit edilmiştir. Öğrenciler tarafından üretilen metaforların temsil ettiği kavramsal kategoriler belirlenerek bütün metaforlara ve ayrıca her kategori altında yer alan metaforlara bulgular kısmında yer verilmiştir. Okul kavramına yönelik üretilen metaforların oluşturduğu altı kavramsal kategoride yer alan her bir metaforun altında toplandığı kavramsal kategoriyi temsil edip etmediğini belirlemek için iki uzman görüşüne başvurulmuştur. Bu süreçte güvenirliği ve inandırıcılığı sağlamaya yönelik uzmanlara metafor listesi ve kategori adları verilmiş ve her bir uzmandan verilen metaforları kavramsal kategorilere yerleştirmeleri istenmiştir. Araştırmacı ve uzmanların yaptığı eşleştirmeler sonucunda bir metaforun farklı kategorilere yerleştirildiği görülmüştür. Miles ve Huberman'ın (1994), (güvenirlik= görüş birliği/görüş birliği+görüş ayrıllı̆ı x100) formülü kullanılarak hesaplanan güvenirlik sonucuna göre, araştırmanın güvenirliği \%97 (Güvenirlik=31/(31+1)x100=0.97) olarak saptanmıştır. Görüş ayrıllı̆ı bulunan 1 metafor uzmanlarla birlikte tekrar incelenerek bu metafor üzerinde de uzlaşma sağlanmıştır. Nitel araştırmalarda 0.90 ve üzeri güvenirlik aranmakta (Saban, 2008) olduğundan bu araştırmanın güvenirliliğinin yeterli olduğu söylenebilir. Ayrıca uzmanlara öğrencilerin doldurduğu formlar 
sunularak oluşturulan kategorilerin kanıtlanabilirliği ve onaylanabilirliği de sağlanmıştır. Öğrencilerin geliştirdikleri metaforların analizi aşağıda açıklandığı üzere dört aşamada yapılmıştır: Kodlama ve ayıklama, kategori geliştirme, verilerin kodlara ve kategorilere göre düzenlenmesi ve tanımlanması, bulguların yorumlanması (Ekiz, 2009; Saban, 2008; Yıldırım ve Şimşek, 2013).

\section{Kodlama ve Ayıklama}

Öğrencilere elden dağıtılıp tekrar elden toplanan 124 form incelenerek formların hepsinin geçerli olduğu görülmüştür. Öğrencilerden toplanan formlara numara verilmiş ve araştırmacı tarafından bu numaraları belirten ifadelerle kodlanarak yazılmıştır (Ö1, Ö2, Ö3 ...). Öğrencilerin geliştirdikleri metaforlar ve gerekçeleri de incelenerek yazılan gerekçenin geliştirilen metaforlara uygun olduğu saptanmıştır.

\section{Kategori Geliştirme}

Öğrencilerin geliştirdiği metaforlar ve bu metaforların gerekçelerinin yer aldığı bir tablo oluşturulmuş ve okul kavramına yönelik üretilen metaforlar ve gerekçeleri arasındaki ilişkiler analiz edilerek birbiriyle ilgili olanlar bir araya getirilmiş ve kategoriler oluşturulmuştur. Öğrencilerin okul kavramına yönelik ürettikleri 32 metaforun güvenli ve huzur verici okul, eğlendirici okul, aydınlatıcı ve bilgilendirici okul, yönlendirici okul, şekillendirici okul, ve çalışma yeri olarak okul olarak altı kavramsal kategoride toplandığı tespit edilmiştir.

\section{Verilerin Kodlara ve Kategorilere Göre Düzenlenmesi ve Tanımlanması}

$\mathrm{Bu}$ aşamada elde edilen veriler geliştirilen kategorilere göre düzenlenmiştir. Veriler tanımlanıp yorumlanmıştır.

\section{Bulguların Yorumlanmast}

$\mathrm{Bu}$ aşamada bulgular yorumlanarak doğrudan alıntı şeklinde öğrencilerin görüşlerine yer verilmiştir.

\section{Bulgular}

Bulgular bölümünde öğrencilerin okul kavramına yönelik ürettikleri metaforlar, üretilen metaforlardan elde edilen kavramsal kategoriler ve her bir kavramsal kategoride yer alan metaforlar ayr1 ayrı verilmiştir. Ayrıca doğrudan alıntılarla, bulgular desteklenmeye çalışılmıştır.

\section{Okul Kavramına Yönelik Üretilen Metaforlar}

Öğrenci görüşlerine göre okul kavramına yönelik 32 metafor tespit edilmiş olup bu metaforlar Tablo 1'de gösterilmektedir. 
Tablo 1: Öğrencilerin okul kavramına yönelik ürettikleri metaforlar

\begin{tabular}{llll}
\hline Metafor & f & Metafor & f \\
\hline Lunapark & 10 & Bilgisayar & 3 \\
Oyun & 9 & Cennet & 3 \\
Ev & 9 & Fabrika & 3 \\
Aile & 8 & Firın & 2 \\
Yuva & 7 & Değirmen & 2 \\
Günes & 7 & Karınca yuvasi & 2 \\
Harita & 6 & Bilgi yuvası & 1 \\
Pusula & 5 & Fabrika & 1 \\
Anne & 5 & Araba aynası & 1 \\
Fener & 5 & Internet & 1 \\
Tiyatro & 5 & Dergi & 1 \\
Anahtar & 4 & Kitap & 1 \\
Baba & 4 & Hastane & 1 \\
Arı kovanı & 4 & Huzurevi & 1 \\
Park & 4 & Resim atölyesi & 1 \\
Kütüphane & 4 & & \\
Lamba & 4 & Toplam & $\mathbf{1 2 4}$ \\
\hline
\end{tabular}

Tablo 1'de görüldüğ̈̈ üzere öğrencilerin "okul" kavramına yönelik 32 adet metafor ürettikleri görülmektedir. Öğrencilerin okul kavramını en çok lunapark (10), oyun (9), ev (9), aile (8), yuva (7), güneş (7), harita (6), pusula (5), anne (5) fener (5) ve tiyatro (5) metaforlarıyla açıkladıkları saptanmıştır. Tabloda "fabrika" meteforuna birden fazla yer verilmesinin nedeni, öğrencilerin fabrika metaforuna yönelik yaptıkları açıklanmaların farklı olması ve dolayısıyla farklı kategorilere alınmasıdır. Dolayısıyla fabrika metaforu hem "şekillendirici okul", hem de "çalışma yeri olarak okul" kategorilerinde yer almaktadır.

\section{Okul Kavramına Yönelik Üretilen Metaforlardan Oluşturulan Kavramsal Kategoriler}

Öğrenciler tarafından okul kavramına yönelik üretilen 32 metafor, altı kavramsal kategoride toplanmıştır. Bu kategoriler Tablo 2 'de gösterilmektedir.

Tablo 2: Öğrencilerin okul kavramına yönelik ürettikleri metaforlardan oluşturulan kavramsal kategoriler

\begin{tabular}{llc}
\hline Kategoriler & f & \% \\
\hline Güvenli ve huzur verici okul & 38 & 30.6 \\
Eğlendirici okul & 28 & 22.6 \\
Aydınlatıcı ve bilgilendirici okul & 27 & 21.7 \\
Yönlendirici okul & 16 & 13.0 \\
Şekillendirici okul & 8 & 6.5 \\
Çalışma yeri olarak okul & 7 & 5.6 \\
Toplam & 124 & 100 \\
\hline
\end{tabular}

Tablo 2'de görüldüğg̈ üzere öğrencilerin okul kavramına yönelik ürettikleri metaforların toplandığı kategoriler güvenli ve huzur verici okul $(\mathrm{f}=38)$, eğlendirici okul $(\mathrm{f}=28)$, aydınlatıcı ve 
bilgilendirici okul ( $\mathrm{f}=27)$, yönlendirici okul $(\mathrm{f}=16)$, şekillendirici okul $(\mathrm{f}=8)$ ve çalışma yeri olarak okul (f=7) olarak tespit edilmiştir. Öğrencilerin okul kavramına yönelik ürettikleri metaforların "güvenli ve huzur verici" ile "eğlendirici" okul kategorilerinde yoğunlaştığı görülmektedir.

\section{Güvenli ve Huzur Verici Okul}

Öğrencilerin ürettikleri metaforlardan güvenli ve huzur verici okul kategorisi altında yer alanlar Tablo 3'te gösterilmektedir.

Tablo 3: Güvenli ve huzur verici okul kategorisinde yer alan metaforlar

\begin{tabular}{lll}
\hline Kategori 1: Güvenli ve huzur verici okul & \\
\hline Kodlar & $\mathbf{f}$ & $\mathbf{\%}$ \\
\hline Ev & 9 & 23.7 \\
Aile & 8 & 21.1 \\
Yuva & 7 & 18.4 \\
Anne & 5 & 13.2 \\
Baba & 4 & 10.5 \\
Cennet & 3 & 7.9 \\
Hastane & 1 & 2.6 \\
Huzurevi & 1 & 2.6 \\
Toplam & $\mathbf{3 8}$ & $\mathbf{\%} \mathbf{1 0 0}$ \\
\hline
\end{tabular}

Tablo 3'te görüldüğ̈ üzere güvenli ve huzur verici okul kategorisinde öğrenciler tarafından en çok üretilen metaforların ev $(\mathrm{f}=9)$, aile $(\mathrm{f}=8)$ ve yuva $(\mathrm{f}=7)$ olduğu tespit edilmiştir. İlkokul öğrencilerinin çocukluk döneminde olmaları, yaş itibariyle kendilerini koruyacak öz güvenlerinin olmaması nedeniyle onların okulu ev, aile ve yuvaya benzetmeleri normal karşılanabilir. Dahası ilkokul çağındaki çocukların evden sonra kendilerini güvende hissettikleri yerin okul olduğu söylenebilir. Öğrencilerin güvenli ve huzur verici okul kategorisi altında ürettikleri metaforlara ilişkin görüşlerinden bazıları şu şekildedir:

Ev: "Okul bizim evimiz gibidir" (Ö12), "Okulda kendimi evim gibi güvende hissediyorum" (Ö23), Aile: "Öğretmenim ve arkadaşlarım ailem gibiler" (Ö3), Yuva: "Okul benim yuvamdır. Evimden sonra kendimi okulumda güvende hissediyorum" (Ö85), Huzurevi: "Yaşlıların huzurevinde bulduğu huzuru ben okulumda buluyorum" (Ö25), Cennet: "Okulda oyun, arkadaşlar resim, müzik her şey çok güzel. Sanki cennet (Ö76), Anne: "Okulum annem gibi beni korur" (Ö8).

\section{Eğlendirici Okul}

Öğrencilerin ürettikleri metaforlardan eğlendirici okul kategorisi altında yer alanlar Tablo 4'te gösterilmektedir. 
Tablo 4: Eğlendirici okul kategorisinde yer alan metaforlar

\begin{tabular}{lll}
\hline Kategori 2: Eğlendirici okul & & \\
\hline Kodlar & $\mathbf{f}$ & $\mathbf{\%}$ \\
\hline Lunapark & 10 & 35.7 \\
Oyun & 9 & 32.1 \\
Tiyatro & 5 & 17.9 \\
Park & 4 & 14.3 \\
Toplam & $\mathbf{2 8}$ & $\mathbf{\% ~} \mathbf{1 0 0}$ \\
\hline
\end{tabular}

Tablo 4'te görüldüğü üzere eğlendirici okul kategorisinde öğrenciler tarafindan üretilen metaforların lunapark $(\mathrm{f}=10)$, oyun $(\mathrm{f}=9)$, tiyatro $(\mathrm{f}=5)$ ve park $(\mathrm{f}=4)$ olduğu tespit edilmiştir. Öğrencilerin okulu lunapark, oyun, tiyatro ve parka benzetmeleri bulundukları yaş itibariyle oyun çağında olmalarından kaynaklanıyor olabilir. Nitekim bu çağ çocukları için ciddi bir uğraş olan oyun, aynı zamanda bir eğlence ve öğrenme kaynağıdır. İlkokul öğrencileri oyun oynayarak hem öğrenirler hem de eğlenirler. Oyun bu yaşlarda bir ihtiyaçtır. Oyunun çocukların fiziksel, psikomotor, duygusal, sosyal ve bilişsel gelişimine katkısı göz önünde bulundurulduğundan, öğrencilerin okulu lunapark, park ve oyun olarak görmeleri onların okulun bu gelişimlerine katkı sunması bakımından önemli olduğu söylenebilir.

Öğrencilerin eğlendirici okul kategorisi altında ürettikleri metaforlara ilişkin görüşlerinden bazıları şu şekildedir:

Lunapark: "Okulda ben çok ĕgleniyorum. Lunaparkta ĕ̆lendiğim gibi" (Ö55),

Oyun: "Okulda çok oyun var. Arkadaşlarımla birçok oyun oynuyorum" (Ö14),

Tiyatro: "Birçok tiyatro oynuyoruz. Öğretmenimiz de tiyatrocu gibi" (Ö98),

Park: "Okulda pek çok oyun oynuyoruz. Parka gitmiş gibi oluyorum" (Ö65).

\section{Aydınlatıcı ve Bilgilendirici Okul}

Öğrencilerin ürettikleri metaforlardan aydınlatıcı ve bilgilendirici okul kategorisi altında yer alanlar Tablo 5'te sunulmuştur.

Tablo 5: Aydınlatıcı ve bilgilendirici okul kategorisinde yer alan metaforlar

\begin{tabular}{lll}
\hline Kategori 3: Aydınlatıcı ve bilgilendirici okul & \\
\hline Kodlar & $\mathbf{f}$ & $\%$ \\
\hline Güneş & 7 & 26.0 \\
Fener & 5 & 18.5 \\
Kütüphane & 4 & 14.8 \\
Lamba & 4 & 14.8 \\
Bilgisayar & 3 & 11.1 \\
Bilgi yuvasi & 1 & 3.7 \\
İnternet & 1 & 3.7
\end{tabular}




\begin{tabular}{lll} 
Dergi & 1 & 3.7 \\
Kitap & 1 & 3.7 \\
Toplam & $\mathbf{2 7}$ & $\mathbf{\% 1 0 0}$ \\
\hline
\end{tabular}

Tablo 5 incelendiğinde, aydınlatıcı ve bilgilendirici okul kategorisinde öğrenciler tarafından en çok üretilen metaforların güneş $(f=7)$, fener $(f=5)$, kütüphane $(f=4)$ ve lamba $(f=4)$ olduğu tespit edilmiştir. Öğrencilerin aydınlatıcı ve bilgilendirici okul kategorisi altında ürettikleri metaforlara yönelik görüşlerinden bazıları şu şekildedir:

Güneş: "Okulumuz bizi Güneşin Dünyayı aydınlattı̆ğ gibi bilgisiyle aydınlatıyor" (Ö45),

Fener: "Okulumuz beni fenerin geceleri yolumuzu aydınlattığı gibi okulda öğrendiğimiz bilgilerle geleceğimizi aydınlanacak, meslek sahibi olacă̆ız" (Ö88),

Kütüphane: "Kütüphanemizde bilgileri ögrendiğimiz gibi okulumuzda bize çok bilgi veriyor" (Ö106),

Bilgi yuvası: "Okulumuzda birçok bilgi öğreniyoruz." (Ö62).

\section{Yönlendirici Okul}

Öğrencilerin ürettikleri metaforlardan yönlendirici okul kategorisi altında yer alanlar Tablo 6'da sunulmuştur.

Tablo 6: Yönlendirici okul kategorisinde yer alan metaforlar

\begin{tabular}{|c|c|c|}
\hline \multicolumn{3}{|c|}{ Kategori 4: Yönlendirici okul } \\
\hline Kodlar & $\mathbf{f}$ & $\%$ \\
\hline Harita & 6 & 37.5 \\
\hline Pusula & 5 & 31.2 \\
\hline Anahtar & 4 & 25.0 \\
\hline Araba aynası & 1 & 6.3 \\
\hline Toplam & 16 & $\% 100$ \\
\hline
\end{tabular}

Tablo 6 incelendiğinde, yönlendirici okul kategorisinde öğrenciler tarafından üretilen metaforların harita ( $\mathrm{f}=6)$, pusula $(\mathrm{f}=5)$, anahtar $(\mathrm{f}=4)$ ve ayna $(\mathrm{f}=1)$ olduğu tespit edilmiştir. Öğrencilerin ilkokulda okulun kendilerini yönlendirdiğini, kendilerine rehberlik ettiğini düşünmeleri olumlu bir durum olarak görülebilir. Çünkü 21. yüzyılda bilim ve teknoloji öyle hızla gelişiyor ve değişiyor ki, öğrencilerin bu gelişme ve değişimlerden haberdar olmaları bu gelişime ve değişimlere uyum sağlamaları gerekmektedir. Bu da okullarda yönlendirme ve rehberlik çalışmalarını gerekli kılmaktadır. Dahası problem çözme, yaratıcı ve eleştirel düşünme, karar verme becerisi, yenilikçilik, bilgi okuryazarlı̆̆ önemli bir yeri olduğu düşünülmektedir. Bu bulgu, öğrencilerin yönlendirmeye olumlu baktıkları şeklinde yorumlanabilir. Dolayısıyla öğrencilerin okulu yönlendirici bir yer olarak görmeleri bu becerilerin kazandırılmasına önemli bir katkı sunabilir.

Öğrencilerin yönlendirici okul kategorisi altında ürettikleri metaforlara yönelik görüşlerinden bazıları şu şekildedir: 
Harita: "Haritaya bakarak yolumuzu bulabiliyoruz. Okulda da öğretmenimiz bize ne yapmamı gerektiğini ögretiyor" (Ö46),

Pusula: "Okul bize hangi olaylarda nasıl davranacă̆ımızı göstererek yön verir" (Ö28),

Anahtar: "Okul anahtar gibi bana çok güzel kapıları açıp meslek sahibi yapacağını düşünüyorum" (Ö2). Araba aynası: Babam arabımızın aynasına bakarak arabayı sağa sola yönlendiriyor. Okul da bizi çeşitli mesleklere yönlendiriyor. Okuldan sonra meslek sahibi oluyoruz" (Ö60).

\section{Şekillendirici Okul}

Öğrencilerin ürettikleri metaforlardan şekillendirici okul kategorisi altında yer alanlar Tablo 7 'de sunulmuştur.

Tablo 7: Şekillendirici okul kategorisinde yer alan metaforlar

\begin{tabular}{lll}
\hline Kategori 5: Şekillendirici okul & & \\
\hline Kodlar & f & \% \\
\hline Fabrika & 3 & 37.5 \\
Firın & 2 & 25.0 \\
Değirmen & 2 & 25.0 \\
Resim Atölyesi & 1 & 12.5 \\
Toplam & $\mathbf{8}$ & $\mathbf{\% 1 0 0}$ \\
\hline
\end{tabular}

Tablo 7'ye göre öğrencilerin şekillendirici okul kategorisi altında ürettikleri metaforların fabrika $(\mathrm{f}=3)$, firın ( $\mathrm{f}=2$ ), değirmen ( $\mathrm{f}=2$ ) ve resim atölyesi ( $\mathrm{f}=1$ ) olduğu görülmektedir. Şekillendirici okul kategorisi altında üretilen metaforlara yönelik öğrenci görüşlerinden bazıları şu şekildedir:

Fabrika: "Okul bizi fabrika gibi işler ve iyi insan yapar" (Ö17).

Fırın: Fırında ekmekler pişer ya! Biz de okulda çeşitli davranışlar ve bilgiler öğrenerek iyi insan oluruz (Ö9),

Değirmen: "Ben bir buğdayım, değirmenin buğdayı öğ̈̈tüp un yaptı̆̆g gibi. okul da beni ögütecek, iyi bir insan yapacak ve insanlara faydalı olacağım" (Ö91).

\section{Çalışma Yeri Olarak Okul}

Öğrencilerin ürettikleri metaforlardan çalışma yeri olarak okul kategorisi altında yer alanlar Tablo 8'de sunulmuştur.

Tablo 8: Çalışma yeri olarak okul kategorisinde yer alan metaforlar

\begin{tabular}{lcl}
\hline Kategori 6: Çalışma yeri olarak okul & \\
\hline Kodlar & $\mathbf{f}$ & $\mathbf{\%}$ \\
\hline Arı kovanı & 4 & 57.1 \\
Karınca Yuvası & 2 & 28.6 \\
Fabrika & 1 & 14.3 \\
Toplam & $\mathbf{7}$ & $\mathbf{\% 1 0 0}$ \\
\hline
\end{tabular}


Tablo 8'e göre öğrencilerin çalışma yeri olarak okul kategorisi altında ürettikleri metaforların arı kovanı $(\mathrm{f}=4)$, karınca yuvası $(\mathrm{f}=2)$ ve fabrika $(\mathrm{f}=1)$ olduğu saptanmıştır. Öğrencilerin çalışma yeri olarak okul kategorisi altında üretilen metaforlara yönelik görüşlerinden bazıları şu şekildedir:

Arı kovanı: "Öğrenciler arı gibi. Okula giriyorlar, çıkıyorlar, koşuyorlar. Arıların evlerinde çalışarak bize bal yaptıkları gibi biz de okulda arılar gibi çalışıyoruz. Bizim çalışma yerimiz okuldur"(Ö27), Karınca yuvası: "Okulda ögrenciler karınca gibi bahçenin her tarafinda koştururlar. Zil çalınca yuvanın ă̆zından içeri girerler. Sonra tekrar çıkarlar"(Ö120).

\section{Sonuç, Tartışma ve Öneriler}

Bu bölümde araştırmanın bulguları çerçevesinde sonuçlara ve bu araştırmanın sonuçları ile konu ile ilgili literatür kapsamında yorum ve tartışma ile araştırmanın sonuçları doğrultusunda geliştirilen öneriler yer almaktadır.

Araştırma sonucuna göre, öğrenciler okul kavramını 32 metafor ile ifade etmişler ve en çok lunapark, oyun, ev, aile, yuva, güneş, harita, pusula, anne, fener ve tiyatro metaforlarını kullanmışlardır. Öğrencilerin okula yönelik ürettikleri 32 metaforun tümü olumlu kavramlardır. Dolayısıyla öğrencilerin okula karşı olumlu yaklaşımları eğitim öğretim faaliyetlerinin başarıya ulaşmasında ve öğrencilerin eğitiminde öğretmenlere ve okullara kolaylık sağlayacaktır. Dahası ilkokul çağında öğrencilerin okulu olumlu kavramlarla ifade etmeleri, okula yönelik olumlu imajın ortaya çıkması anlamına gelmektedir ve bu olumlu algı aslında öğrencileri yönlendirebilme ve 21. yüzyılın gerektirdiği becerilerle donatarak toplumsal kalkınmanın sağlanmasına da katkı sunacaktır. Literatür incelediğinde öğretmenler ve öğrenciler üzerinde yapılan araştırmalarda (Cerit, 2006; Saban, 2008; Tuncay ve Özçınar, 2009; Özdemir, 2012) okula ilişkin algıların genellikle olumlu olduğu görülmektedir. Kara ve Bozbayındır (2019)'ın aday öğretmenlerle yaptıkları çalışmada okul kavramına ilişkin toplam 199 adet metafor üretilmiş ve okul kavramına yönelik en çok ev, fabrika, bahçe, aile, hayat/yaşam, uzun bir yolculuk, tiyatro salonu, mozaik, yuva, gökyüzü ve gökkuşağı metaforları üretilmiştir. Doğan (2014) tarafından öğretmen adayları ile yapılan çalışmada öğrenciler okulu en çok aile, yuva, hayat, hapishane, ev, fabrika, dünya ve toprak metaforlarıyla; Ateş (2016) tarafından ilkokul ve ortaokul öğrencileri ile yapılan çalışmada öğrenciler okulu en çok ev, hapishane, yuva, bilgi yuvası, hayat ve aile metaforlarıyla; Nalçacı ve Bektaş (2012) tarafından üniversite öğrencileri ile yapılan araştırmada ise öğrenciler okul kavramını en çok aile, ev, yuva, hayat, hapishane, fabrika, toplum, gelecek, güneş, beyin ve gökkuşağı metaforlarıyla ifade etmişlerdir. Arslan (2020) çalışmasında okul kavramına ilişkin metaforları, karınca yuvası, bir toplum olarak okul, bir fabrika olarak okul, hapishane olarak okul, spor stadyumu olarak okul ve gündüz bakımevi olarak okul şeklinde ifade etmiştir. Akan ve Yarım (2019) tarafından yapılan çalışmada da ilkokul öğrencileri okulu en çok ev, bilgi evi, güzel bir yer, park, yuva, kütüphane metaforlarıyla açıklamışlardır. Literatür incelendiğinde bu araştırmada ulaşılan sonuçlarla yapılan çalışmaların sonuçlarının benzerlik gösterdiği ve öğrenciler tarafından okula yönelik algının genel olarak olumlu olduğu görülmektedir. Bu durum öğrencilerin okula yaklaşımlarının pozitif olduğunu 
göstermektedir. Ortaya çıkan bu olumlu ve pozitif algı öğrencilerin eğitilmesinde, yönlendirilmesinde öğretmen, yönetici ve okullara kolaylık sağlayacağı muhtemeldir. Zira okul kavramının hapishane metaforu ile ifade edilmesi istenmeyen bir durum olarak görülebilir. Bu durumun okul yönetim yapılarından ve öğretmenlerin öğrencilere yaklaşımlarından kaynaklandığı düşünüldüğünde, okul yöneticilerinin ve öğretmenlerin öğrencilerin okulu sevmeleri için daha fazla çaba göstermeleri gerektiği söylenebilir. Çünkü sevilmeyen ve olumsuz tutum sergilenen bir yerde eğitimin gerçekleşmesi zor olacaktır. Öğrencilerin öğrenme istek ve heyecanlarının sağlanması ve bu durumun artırılması, öğrenme motivasyonlarının üst düzeye çıkarılması okulların temel görevlerinden biridir. Öğrenciler öğrenme istek ve heyecanını kaybettikleri zaman okul onlar için anlamsız bir hale gelebilmekte ve bu anlamsızlık öğrencilerin hayattan kopuşlarına sebep olabilmektedir (Turan, 2007). Dolayısıyla bu araştırmada özellikle ilkokul öğrencilerinin okula yönelik olumlu algıları, öğrencilerin ailelerinden sonra ikinci eğitim yuvaları olan okulları anlamlı olarak görmeleri açısından, motivasyonlarının artırılmasında, istekli ve heyecanlı bir şekilde öğrenmelerini sağlamada önemli bir sonuç olarak görülmektedir.

Öğrencilerin okul kavramına yönelik ürettikleri metaforlar güvenli ve huzur verici okul, eğlendirici okul, aydınlatıcı ve bilgilendirici okul, yönlendirici okul, şekillendirici okul ve çalışma yeri olarak okul olmak üzere altı kavramsal kategoride toplanmıştır. Öğrenciler okul kavramını en çok güvenli ve huzur verici olarak ifade ederken, en az çalışma yeri olarak ifade etmişlerdir. Öğrencilerin okulu en çok güvenli ve huzur verici olarak ifade etmeleri, ilkokul öğrencilerinin kendilerini koruyacak yaşta olmamalarından dolayı öğretmenlerini birer koruyucu, okullarını da evleri gibi güvenli bir yer olarak görmeleri sonucu ortaya çıkmış olabilir. Okullarda son yıllarda uygulanan özel güvenlik görevlisi uygulamaları da öğrencilerin okula yönelik algılarının güvenli ve huzur verici olmasına katkı sunmuş olabilir. Kara ve Bozbayındır (2019) çalışmalarında okul kavramına yönelik üretilen metaforları sevgi ve güven ortamı, üretim yeri, yaşamın bir parçası, bilgi ve kazanım yeri, şekillendirme ve sosyalleşme yeri, sistemli ve hiyerarşik bir yapı, araç, geleceğin umudu ve güvencesi, disiplin edici ve iş ve çalışma merkezi olarak 11 kategoride toplamışlardır. Saban (2008), ilköğretim birinci kademe öğrencilerinin büyük bir kısmının okulu sevgi ve dayanışma ortamı içerisinde bilgi kazanılan ve aynı zamanda hoş ve güzel vakit geçirilen bir yer olarak nitelendirdiklerini; Ateş (2016) ise çalışmasında ilkokul ve ortaokul öğrencilerinin okulu yüksek düzeyde sevgi ve güven ortamı olarak algıladıklarını tespit etmiştir. $\mathrm{Bu}$ araştırmada da okul kavramı ilkokul öğrencileri tarafından eğlendirici okul olarak güven ve huzur verici okul kategorisinden sonra ikinci sırada yer almaktadır. Bu bağlamda literatürde ulaşılan sonuçlarla bu araştırmada ulaşılan sonuçların benzerlik gösterdiği söylenebilir. Nitekim ilkokul çağındaki öğrenciler oyun çağında oldukları için okulda arkadaşlarıyla birlikte hoş vakit geçirmekten, oyun oynamaktan mutluluk duyacaklardır. Dolayısıyla okulu eğlendirici, güzel ve hoş vakit geçirilen bir yer olarak ifade etmeleri oldukça doğaldır. Akan ve Yarım (2019) tarafından yapılan çalışmada da okul kavramının ifade edildiği metaforların güvenli güzel bir yer, öğretici ve yetiştirici bir yer, eğlence ve oyun merkezi, görkemli ve korunaklı bir yer, hoş ve renkli bir yer kavramsal kategoriler içerisinde yer aldı̆̆ 
saptanmıştır. Bülbül ve Toker-Gökçe (2015) tarafından yapılan çalışmada da okula yönelik metaforların toplandığı bilgi veren ve geliştiren, şekillendiren ve biçimlendiren, eğlenme yeri ve güzel bir ortam olarak okul kategorilerinin bu araştırmada ulaşılan sonuçları desteklediği görülmektedir.

Araştırma sonucuna göre, öğrenciler güvenli ve huzur verici okul kategorisi altında ev, aile, yuva, anne, baba, cennet, hastane, huzurevi; eğlendirici okul kategorisinde lunapark, oyun, tiyatro ve park; aydınlatıcı ve bilgilendirici okul kategorisinde güneş, fener, kütüphane, lamba, bilgisayar, bilgi yuvası, internet, dergi ve kitap; yönlendirici okul kategorisi altında harita, pusula, anahtar ve ayna; şekillendirici okul kategorisi altında fabrika, fırın, değirmen ve resim atölyesi; çalışma yeri olarak okul kategorisi altında arı kovanı, karınca yuvası ve fabrika metaforlarını üretmişlerdir. Ateş (2016) tarafından yapılan çalışmada sevgi ve güven ortamı olarak okul teması altında aile, anne-baba, cennet, ev ve yuva metaforlarının; çalışma ve gelişme yeri olarak okul temasında: arı kovanı, karınca yuvası ve fabrika metaforlarının; güzel ve eğlenceli bir yer olarak okul temasında, oyun alanı ve park metaforlarının; bilgi ve kazanım yeri olarak okul temasında bilgi yuvası, bilgi deposu, bilgi evi, bilgisayar, kitap, kütüphane ve güneş metaforlarının bu araştırmada üretilen metaforlar ve elde edilen katagorilerle örtüştüğü görülmektedir. Bülbül ve Toker-Gökçe (2015) tarafından yapılan çalışmada bilgi veren ve geliştiren bir ortam olarak okul teması altında bilgi yuvası ve kütüphane metaforlarının; Nalçacı ve Bektaş (2012) tarafindan yapılan çalışmada eğlendirici okul kategorisinde tiyatro; bilgi sağlayıcı okul kategorisinde güneş; güven verici okul kategorisinde aile, ev, yuva, cennet, hastane; biçimlendirici okul kategorisinde fabrika; yönlendirici okul kategorisinde ayna metaforlarının bu araştırmada üretilen ve oluşturulan kavramsal kategorilerle benzerlik gösterdiği görülmektedir. Kara ve Bozbayındır (2019) tarafından yapılan çalışmada da sevgi ve güven ortamı kategorisinde ev aile, yuva ve güneş; bilgi ve kazanım yeri kategorisi altında bilgi yuvası, bilgisayar ve kitap; iş ve çalışma merkezi olarak okul kategorisinde karınca yuvası metaforları ve kategorileri bu araştırmanın sonuçları ile benzerlik göstermektedir.

$\mathrm{Bu}$ araştırmada öğrencilerin okul kavramına yönelik ürettikleri ve üretilen metaforlarda elde edilen kavramsal kategorilerin olumlu olması ve literatürde ulaşılan sonuçların da genel olarak benzer yönde olması önemli ve umut verici bir sonuçtur. Çünkü okul çevrelerinde öğrencilerin dikkatini dağıtıcı ve kötü davranışa sevk edici birç̧ok faktörün olduğu göz önüne alındığında, öğrencilerin okulu güvenli ve huzur verici, aydınlatıcı ve bilgilendirici, yönlendirici ve şekillendirici olarak algılamaları öğrencilerin okula güvendiklerini ve okulları geleceklerini aydınlatacak kurumlar olarak gördükleri şeklinde yorumlanabilir. Dolayısıyla öğrencilerin bu olumlu algıları onların okullarda kaliteli bir eğitim alıp iyi bir vatandaş olarak topluma katılmaları ve ülkemizin kalkınmasına katkı sunmaları açısından oldukça önemli görülmektedir. Ayrıca öğrencilerin okulları eğlenceli bir yer olarak görmeleri de önem taşımaktadır. Özellikle ilkokullarda eğitim öğretim faaliyetlerinde oyunlaştırma, oyunun yer aldığı öğretim yöntem ve tekniklerinden sıklıkla faydalanılmaktadır. Dolayısıyla öğrencilerin okulu eğlendirici bir yer olarak görmeleri eğitim öğretim çalışmalarının başarıya ulaştırılmasında önemli bir 
firsat olarak görülebilir. Çünkü oyun, çocukların öğrenmesini sağlamakta, yaratıcılıklarını geliştirmekte, oyun sayesinde çocukların güçlü ve geliştirilebilir yönleri ortaya çıkmaktadır (Öktem, 2018; Akt: TEMDEM, 2018). Sonuç olarak eğitimin en önemli unsurlarından biri olan öğrencilerin okula karşı olumlu algıları onların motivasyon düzeylerinin artırılmasına, yaratıcılıklarının geliştirilmesine, problem çözme, yenilikçilik ve eleştirel düşünme becerilerinin geliştirilmesine katkı sağlayacaktır.

Araştırmanın sonuçları doğrultusunda araştırmacılara ve uygulayıcılara aşağıda öneriler sunulabilir:

Öğrencilerin okulu ev, aile ve yuvaya benzetmeleri özellikle ilkokul çağındaki çocukların ailelerinden ayrılarak okula geldikleri zaman okulda onlara aile ortamını sağlayacak şefkati ve ortamı sağlamayı gerekli kılmaktadır. Bu anlamda okulların öğrencilere evlerindeki rahat ortamı sağlayıcı fiziksel yapılara kavuşturulmaları iyi olacaktır.

$\mathrm{Bu}$ araştırmada ilkokul öğrencileri ile çalışılmıştır. Başka bir araştırmada farklı eğitim kademelerinde öğrenim gören öğrencilerin okula yönelik algıları belirlenerek karşılaştırmalı bir analiz yap1labilir.

İlkokul öğrencilerinin okul kavramına yönelik ürettikleri metaforlar genellikle olumludur. Bu bağlamda öğrencilerin motive edilerek iyi bir eğitim almaları ve iyi bir vatandaş olarak yetiştirilmeleri kolaylaşacaktır. Ayrıca öğrencilerin okulu yönlendirici ve şekillendirici olarak açıklamaları, ögrencilerin yönlendirilmesi ve onlara rehberlik etmede öğretmen ve okul yöneticilerinin daha fazla gayret göstermelerini gerekli kılmaktadır.

Öğrencilerin okulu eğlendirici bir yer olarak görmelerinden dolayı eğitim öğretim faaliyetlerinde oyunlaştırma ve oyuna yönelik öğretim yöntem ve teknikleri sıklıkla kullanılmalıdır. Özellikle ilkokullarda geniş oyun alanlarına yer verilmesi sağlanabilir.

Bugünün çocukları yarının büyükleri olacaktır. Dolayısıyla öğrencilerin okula karşı olumlu algıları bir firsata dönüştürülmeli ve öğrencilerin motivasyon düzeylerinin artırılarak yaratıcılık, problem çözme, yenilikçilik ve eleştirel düşünme becerilerinin geliştirilmesine katkı sunulmalı ve dolayısıyla gelecek neslin iyi bir eğitim alması sağlanarak ülkemizin geleceği güvence altına alınmalıdır.

\section{Kaynakça}

Akan, D. ve Yarım, M. A. (2019). İlkokul öğrencilerinin okul ve okul müdürü kavramlarına ilişkin metaforik algıları. Düzce Üniversitesi Sosyal Bilimler Enstitüsü Dergisi, 9 (2), 223-233.

Arslan, P. (2020). Okul kavramına ilişkin metaforlar. Uluslararası Liderlik Çalışmaları Dergisi: Kuram ve Uygulama, 3 (1), 1-14.

Ateş, Ö. T. (2016). Öğrencilerin öğretmen ve okul metaforları. Uluslararası Güncel Eğitim Araştırmaları Dergisi (UGEAD), 2 (1), 78-93.

Aydın, İ. (2012). Alternatif okullar. Ankara: Pegem Yayıncılık.

Balcı, A. (2015). Sosyal bilimlerde araştırma yöntem, teknik ve ilkeler. Ankara: Pegem Yayıncılık. 
Botha, E. (2009) Why metaphor matters in education. South African Journal of Education, 431-444.

$29(4)$,

Bülbül, T. ve Toker-Gökçe, A. (2015). Meslek lisesi öğrencilerinin metaforik okul algıları: işlevselci bir yaklaşım. Ahi Evran Üniversitesi Kırşehir Eğitim Fakültesi Dergisi （KEFAD) 16 (2), 273291.

Cerit, Y. (2006). Öğrenci, öğretmen ve yöneticilerin okul kavramıyla ilgili metaforlara ilişkin görüşleri. Kuram ve Uygulamada Eğitim Bilimleri, 6 (3), 669-699.

Dewey, J. (2019). Okul ve toplum (H. A. Başman, Çev.). Ankara: Pegem Akademi Yayınevi.

Doğan, D. (2014). Öğretmen adaylarının perspektifinden okul kavramının metaforlarla analizi. Kuramsal Eğitimbilim Dergisi, 7 (3), 361-382.

Ekiz, D. (2009). Bilimsel araştırma yöntemleri (2. baskı). Ankara: Anı Yayıncılık.

Kara, M. ve Bozbayındır, F. (2019). Aday öğretmenlerin okul kavramına ilişkin algıları: Bir metafor çalışması. Anadolu Türk Eğitim Dergisi, 1 (1), 18-34.

Lakoff, G. ve Johnson, M. (2005). Metaforlar: Hayat, anlam ve dil (G. Y. Demir, Çev.). İstanbul: Paradigma.

Mazlum, A. A. ve Balcı A. (2018). Meslek lisesi öğretmen ve öğrencilerine göre okul: bir metafor çalışması. Mehmet Akif Ersoy Üniversitesi Eğitim Fakültesi Dergisi, 47, 1-26. https://doi.org/10.21764/maeuefd.339901.

Merriam, S. B. (2013). Nitel araştırma: Desen ve uygulama için bir rehber (S. Turan, Çev.). Ankara: Nobel Akademik Yayınc1lı.

Miles, M. B.ve Huberman, A. M. (1994). An expanded sourcebook qualitative data analysis. Thousand Oaks, California: Sage Publications.

Nalçacı, A. ve Bektaş, F. (2012). Öğretmen adaylarının okul kavramına ilişkin algıları. Ahi Evran Üniversitesi Kırşehir Eğitim Fakültesi Dergisi (KEFAD), 13 (1), 239-258.

Örücü, D. (2014). Öğretmen adaylarının okul, okul yönetimi ve Türk eğitim sistemine yönelik metaforik algıları. Kuram ve Uygulamada Eğitim Yönetimi Dergisi, 20 (3), 327-358.

Özdemir, M. (2012). Lise öğrencilerinin metaforik okul algılarının çeşitli değişkenler açısından incelenmesi. Eğitim ve Bilim, 37 (163), 97-109.

Saban, A. (2008). Okula ilişkin metaforlar. Kuram ve Uygulamada Eğitim Yönetimi, 55, 459- 496.

TEDMEM (2018, Ocak). Prof. Dr. Ferhunde Öktem ile Düşünme Becerileri ve Oyun Üzerine. Erişim adresi: https://tedmem.org/dosya-konusu/prof-dr-ferhunde-oktem-ile-dusunme-becerilerioyun-uzerine.

Tuncay, N. ve Özçınar, Z. (2009). Distance education students' metaphors. Procedia Social and Behavioral Sciences, 1, 2883-2888. https://doi.org/10.1016/j.sbspro.2009.01.513.

Turan, S. (2007). İşini bil okuluna sahip ol. A. Açıkalın, M. Şişman, S. Turan, (Ed.). Bir insan olarak okul müdürü kitabı içinde (ss.81-100). Ankara: Pegem A Yayıncılık.

Yıldırım, A. ve Şimşek, H. (2013). Sosyal bilimlerde nitel araştırma yöntemleri (9. Baskı). Ankara: Seçkin Yayınevi.

Yıldırım, K. (2010). Nitel araştırmalarda niteliği artırma. İlköğretim Online, 9 (1), 79-92.

Yin, R. K. (2003). Case study research. design and methods (3nd.). Thousand Oaks, CA: Sage.

Yob, I. M. (2003). Thinking constructively with metaphors. Studies in Philosophy and Education, 22 (2), 127-138. https://doi.org/10.1023/A:1022289113443. 